\title{
Social Advance of Rural Society and the Role of Islamic Economy
}

\author{
M Elfan Kaukab ${ }^{1 *}$, Nurul Mubin², Imam Ariono ${ }^{3}$ \\ ${ }^{1}$ Faculty of Economics, Universitas Sains Al-Quran Jawa Tengah, Wonosobo, Indonesia \\ ${ }^{2}$ Faculty of Education and Teaching, Universitas Sains Al-Quran Jawa Tengah, Wonosobo, Indonesia \\ ${ }^{3}$ Faculty of Sharia and Law, Universitas Sains Al-Quran Jawa Tengah, Wonosobo, Indonesia \\ *Corresponding author. Email: elfan@unsiq.ac.id
}

\begin{abstract}
The current economic system is counterproductive for human development because it encourages the lowerclass society to be consumptive by buying more than what they can afford. This impacts on the long-term social-economic problems, especially for society in the rural areas that have been contaminated to urban life. The purpose of this article is to build a conceptual framework of the role of Islamic economy for the social advance of the rural society. The framework builds from the theory of societal human capabilities. To achieve the goal, the researchers conducted literary and conceptual studies to relate the Islamic economic elements with the elements of the societal human capabilities' theory. This results in the formalization of a ruralsociety developmental framework that is based on three Islamic economy elements namely entrepreneurship, no-usury fund management, and wealth redistribution. The framework reiterates the importance of the government to encourage entrepreneurship, sharia finance, and wealth redistribution in rural society to make them better personally and structurally based on the Islamic economy.
\end{abstract}

Keywords: Islamic economy, social advance, rural society, societal human capabilities

\section{INTRODUCTION}

For centuries social scientists have tried to generate theories capable of realizing social advance. Henri Saint Simon and Auguste Comte started this effort and stated that social science should contribute to community development by being a basis for the nation's development [1], [2]. This movement is welcomed and begins to shift the older paradigm in Europe, which is either based on laissez-faire (abstention by governments from interfering in the workings of the free markets) or on Social Darwinism (natural selection) [1].

The modernization theory is the major theory in guiding social policies post World War II. It argues that the best way towards prosperity is through the economic ways, in which the government provides minimum intervention and the private sectors maximally exploit economic resources. This kind of capitalism is deemed to erase obstacles in the development and create evenly-distributed social advance [3]. It happens in trickling down effect, in which the wealth's welfares lead to the lower class' welfares through an increase in efficiency and decrease in unemployment. However, the increase of the upper class' welfare brings capital-intensive industries instead of labor-intensive industries, the one needed by the unemployed. The effect that happens is contrary to the main goal. The upper class' welfare leads to the flow of luxury items to the lower class' market. The media have us informed of the extravagant lifestyle lead by lower-class society. This lifestyle has made them purchasing luxurious items beyond their economic capability [4]. In time, the lower class' society is highly in debt due to their beyond-income consumption. They spend more than what they earn.

Many countries in Asia, including Indonesia, apply modernization-theory based policies. Nevertheless, the main goal, which is welfare, is often times neglected for economic development. Experts call these Asian countries as productive-welfare regimes, as they believe the connection between productivity and welfares [5].

In 1971, Seers criticized this approach and stated that development should focus on the social phenomena leading to the direct reduction of poverty, unemployment, and inequality [6]. Capitalism will only create a bigger gap between the haves and the poor since economic development eliminates the hope of welfare instead of nourishes it [7]. As a consequence, there should be a downflow from the capitalists to the poor society to drag them out of desperation.

The awareness of this fact has begun to generate a normative theory of social development, in which the economic agenda is synchronized with the social agenda [3]. This theory sees that inherently, economic development and social development will tear each other down. The focus on social development will result in low economic development. On the other hand, the focus on economic development will yield in welfare dependency. The government should interfere in harmonizing both to obtain the best result.

Later on, Aspalter proposed the theory of societal human capabilities [8]. This theory lies in the social system theory [9] stating that human individual minds contribute to the social system and the social system affects human minds. The effect of the social system on human minds results in societal human capabilities, which comprise of human 
capability, social capability, and cultural capability. These capabilities also affect the social boundaries faced by humans collectively, whether in family, community, or society. Thus, social policies aimed at the development of individual capability will influence the family, community, and society.

Nevertheless, this theory does not gain much support from academicians. There is no article quoting Aspelter but Aspelter himself in the last five years. We put forward this theory and build its connection to the Islamic economy and social advance in the rural society of Indonesia. We would like to show that the Islamic economy and social advance of rural society can strongly be related using Aspalter's theory of societal human capabilities.

\section{METHOD}

To address the problem of Islamic economy and social advance of rural society, we applied the theory of Societal Human Capabilities. Theory of Societal Human Capabilities sees that economic development is just one aspect of social advance. Overall, societal development is human, society, culture, politic, administration, and economic development. There are nine elements of societal development, namely free of discrimination, healthy, educated, economically prosperous, territorial freedom, political freedom, socially capable, cultured, and safe [8].

\section{RESULTS AND DISCUSSION}

Rural society has experienced many of the social advances above-mentioned. From the economic side, rural society's dependency on farming has created quite an income gap between rural and urban areas [10]. Poverty in the rural areas is worsened after the 2008 crisis when the developing countries began to experience a sharp increase in foreign debts and farming programs were cut [10]. In fact, national economic development does not necessarily bring social advance to rural society. This makes the rural young generation migrates from their villages to cities to have education and works. Therefore, the income gap is getting bigger. This gap can be more or less reduced by the cash flow brought by rural society working in urban areas. However, this has reduced the number of labors in rural areas. It has also encouraged rural society to work on easy jobs or have monoculture farming.

We can easily draw various issues other than economic in rural life based on Aspalter typology. Rural society has fewer health facilities, limited transportation, less territorial freedom, inadequate education facilities, more susceptibility to discrimination, less ability to have social relations outside, more chances to be subjects of political polarity, and more vulnerability to become victims of wider social conflicts. It is only in the cultural aspect that rural society excels from urban society.

Some authors realized that cultural capability is the best capability possessed by rural society [11]. Generally, this capability has generated a creative economy that can sustain the rural life in a certain proportion [12].
One of the cultural elements of rural society is religion. Rural society is considered to be more religious than urban society [13]. Cox sees that religion is the source of social advance because it gives universal emphasis on spiritual, ethical, and lifestyle dimensions that regard all living creatures as sacred [13]. The two main operations of religion's effects on social advance are religious institutions that fulfil the spiritual needs and Faith-Based Organization (FBO) that become philanthropist foundations to provide society's welfare and social-economic development [14]. While we are in favor of Cox's view, we also consider that religion's contribution to rural society's social advance is beyond the institutional aspect. The systemic aspect, particularly in Islam, is more capable of providing greater social advance. This is even a more basic aspect because it gives energy to both the institution and the FBO to perform their function in society's development.

The systemic aspect of playing a role in the social advance of rural society in the Islamic economic system. It has three major characteristics that allow the social advance of rural society. First, it encourages entrepreneurship. Prophet Muhammad was a merchant prior to his ascendance as a prophet. Teachings in Al Qur'an and Sunnah also contain regulations of trading activity and entrepreneurship in general. The activity is regarded as a part of human's piety in living his life as a manager (caliph) of earth. Islamic entrepreneurship characteristics that connect entrepreneurship and spirituality had become an economic driving force in the Indian Ocean in the past. Islam civilization had dominated trades in this area before the Europeans came and conquered them in armed violence. The Islamic economic system has created several instruments to support entrepreneurship. As an example, an entrepreneur can seek capital aid by cooperating with a financier in a mudarabah agreement [15]. If a loss is suffered, the financier will bear it. But, if profit is gained, both parties will get their share according to their previously-determined agreement. This system supports entrepreneurship more than an interest-based loan system. The latter system demands payment regardless of the entrepreneur's loss. If he fails to pay, he will also have to pay the fine. This makes an entrepreneur economically stressed.

The above problem directly relates to the second aspect that allows the Islamic economy encourages social advance, which is usury-free finance practice. Usury or interest is something forbidden in the Islamic economic system. An individual or an institution loaning money is prohibited to collect interest from it. Islam teaches that loan is allowed only in urgent situations. If the loan is used for trading, the contract should be profit-sharing like mudarabah. According to Choudhury, usury prohibition implicates the absolute relationship of financial value and economic value [16]. This means that the increased value of money is in line with the real increased economic profit [16]. It will prevent wrong inflation which is caused by the different financial and economic values. Moreover, absolute connectivity, in turn, will activate fund mobilization towards actual resources development because there will be no advantage for someone to keep or trade his money. Fund will always be rotated in the economy and thus expand the related 
aspects such as labor, profit, equity, efficiency, and social security. All these are important in social advance.

Third, the urge to have welfare distribution. It is also related to the second aspect since, in Islam teachings, God forbids usury and encourages society to have advantages from the money they own by giving it to the needy. There are four instruments to do it, abbreviated as ZISWAF (Zakat, Infaq, Sedekah, and Wakaf). Zakat is a mandatory contribution given away in welfare distribution. Infaqis a voluntary financial contribution to the less fortunate. Sedekah is a voluntary non-financial contribution also to the less fortunate, while wakaf is a voluntary contribution in the forms of properties for commonweal and/or worship. ZISWAF enables the social advance cycle to cover the overall society as it includes the poor and the less fortunate into the economic system. Specifically, zakat is administered by an institution that functions to collect and distribute it [17]. It is estimated that there is $\mathrm{Rp} 100$ trillion zakat potential per year in Indonesia, but only $1,1 \%$ can be collected by the national amil zakat institution [18].

These three things' relation to the social advance of the rural society can be seen in Figure 1. Contrary to Aspalter's belief that cultural capability cannot be used for education and politic, we argue that Islamic economy allows rural society's increased education and politic. Islamic economy enables funds to flow into Islamic educational institutions which in turn boost the economy through pesantren-based (Islamic boarding school) or madrasa-based entrepreneurship. It also permits funds to circulate in the society to support empowerment and more-active political participation, for example, wakaf makes it possible for the society to have a place to gather and have a discussion.

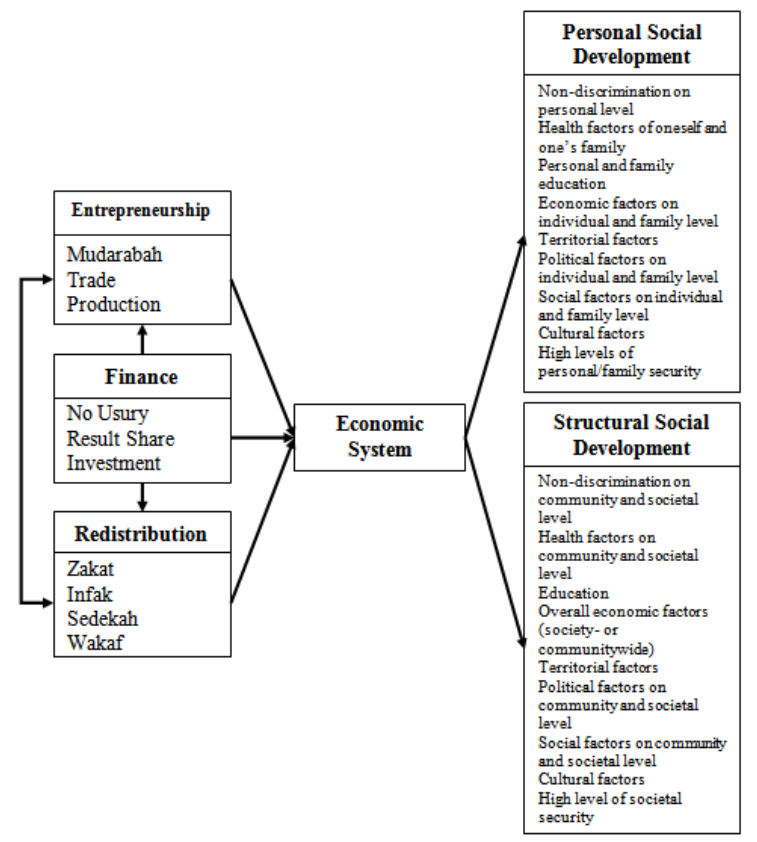

Figure 1 Broad Conceptual Framework

Figure 1 explains the relation of the Islamic economic system to nine elements of societal development according to the theory of Societal Human Capabilities. While the system works as whole to advance personal and structural social development, we pointed several aspects of the system to highlight the system's role in social development. First, the system against discrimination. The principle of distribution enables villagers from the lowest status to gain help from villagers from higher status. Besides zakat which is defined in terms of specific financial amount, there is infak, which essentially donation without specific amount and without specific time.

Second, the economic system fosters health in society, at least for psychological health. We could view spiritual health as part of psychological health. Increased religiosity would benefit the psychological health while economic system would provide better allocation of health resources. For education, the system would increase the minimum standard for education, even this means would sacrifice the highest education standard available in the village. Here, redistribution also takes place to help the poor.

Next, economic prosperity maintained by continuous production of goods and services. Consumption rate would relate to society's incomes as a whole since the poor also consume, subsidized by the rich. The poor also take part in the production system in any form imaginable by the society, funded by the rich and alms fund.

Fifth, the social and physical movement guaranteed by the economic system. The system is not closed. It open to any space outside the village. Information technology even makes the internationalization of local producer possible.

Political development will have a new dimension, created by religious system. Some would think that religiosity is a valuable political asset and strive for it. Since the support to redistribution is part of religious image, the economic system also feeds the political system.

Social capability development will be entangled with economic system since financial institutions highly connected with social system. Bank's social responsibility aimed at social development will sought to mitigate any potential social conflict, hand in hand with police.

Culture also gains a new dimension. Redistribution is the new norm in the village, and generosity becomes values for society around the village. Collectivism may be already suited to these norms. However, collectivism is a closed system. The redistribution principle will redefine who is the part of in-group and who is a member of out-group. The group potentially larger since Islam is transcended ethnic groups or whether a person is outsider or native.

Finally, safety will be enhanced by financial system. When everyone contributes to the system, trust emerges and anyone becomes helpful to somebody. The poor would help by the security system since they are the most unsafe member of society. Meanwhile, the rich would protect by community as valuable assets and even without formal guards, the society already worked as informal guardians. Islamic economic system able to advance the village society in terms of discrimination, health, education, economic prosperity, movement, politics, social, cultural, and safety [8]. The system works best in very sick society when the distribution of wealth between member of the society extremely large. This would be revolutionary, as long as the leadership and the support system, including government, able to bring change to the village.

The system of course, not without its weakness. Islam is a religion, hence in itself, a form of a social group. Non- 
[7] D. Donnison, "Foreword," in Economic Growth, Low Income and Housing in South Korea, Hampshire: Macmillan Press Ltd, 1997, pp. xi-xii.

[8] C. Aspalter, "Towards a More Society-Centered Paradigm in Social Development," Asian J. Soc. Policy, vol. 2, no. 1, pp. 65-86, 2006.

[9] N. Luhmann, Social Systems. Stanford: Stanford University Press, 1995.

[10] M. de Lattre-Gasquet and C. Moreau, "The Global Context," in Land Use and Food Security in $2050:$ a Narrow Road, C. Le Mouël, M. de Lattre-Gasquet, and O. Mora, Eds. 2018, pp. 79-100.

[11] K. Scott, F. Rowe, and V. Pollock, "Creating the good life? A wellbeing perspective on cultural value in rural development," J. Rural Stud., vol. 59, pp. 173$182,2018$.

[12] D. E. Beel et al., "Cultural resilience: The production of rural community heritage, digital archives and the role of volunteers," J. Rural Stud., vol. 54, pp. 459-468, 2017.

[13] M. N. Asadullah, "Madrasah for Girls and Private School for Boys? The Determinants of School Type Choice in Rural and Urban Indonesia," Int. J. Educ. Dev., vol. 62, pp. 96-111, 2018.

[14] D. Cox, "Religion, the Spiritual Dimension and Social Development," in Future Directions in Social Development, J. Midgley and M. Pawar, Eds. Berkeley, California: Palgrave Macmillan, 2017, pp. 187-204.

[15] A. A. A. Ibrahim, "A Suggested EFL Program for Islamic Economics Translation in Sudanese Institutes: A Case Study of Islamic Bank, Islamic Funds, (2016)," University of Gezira, 2017.

[16] M. A. Choudhury, "Usury," Encyclopaedia of the Qur'an: Vol. 5 Si-Z. Brill, Leiden, pp. 406-408, 2006.

[17] K. A. Rashid, S. F. Hasan, and A. A. Sarkawi, "Haddul kifayah: its comprehensiveness, sufficiency, and currency in meeting the needs of the asnaf faqr and asnaf miskin," in Proceedings of the National Conference on Zakat and Economic Development, 2015, pp. 228-249.

[18] U. K. Yaumidin, D. S. Suhodo, P. I. Yuniarti, and A. Hidayatina, "Financial Inclusion for Women: Impact Evaluation on Islamic Microfinance to Women's Empowerment in Indonesia," in Financial Inclusion and Poverty Alleviation, Cham, Switzerland: Palgrave Macmillan, 2017, pp. 81-140.

[6] D. Seers, Development in a Divided World.

Penguin: Harmondsworth, 1971. 